\title{
ARBEIDSREGTELIKE ONTWIKKELING VAN DIE GEMENEREG: QUO VADIS?
}

\section{$1 \quad$ Inleiding}

Gedurende die afgelope paar jaar het interessante tendense in arbeidsregtelike verband neerslag gevind - tendense wat aan die een kant deur regspragmatisme gekenmerk word en te verwelkom is, maar aan die ander kant, ander wat deur 'n stremmende bekommernis oor onnodige dualisme gekenmerk word en voorgaande tendense neutraliseer.

Die Suid-Afrikaanse arbeidsverhoudinge-dinamika is verteenwoordigend van die "regswoelinge" wat die afgelope aantal jare hierdie aktuele terrein van die reg gekenmerk het. In die resente en nou reeds bekende uitspraak van Gcaba v Minister for Safety \& Security (2009 30 ILJ 2623 (KH)) is die volgende insiggewende uitlating deur die Konstitusionele Hof gemaak wat van bogemelde gedagtes onderlê en realisties tipeer: "Yet the legislature, courts, legal representatives and academics often create complexity and confusion rather than clarity and guidance. In the case of fairly new legislation based on a young Constitution this is perhaps understandable" (2627 par [2], my kursivering; sien ook Makambi v MEC, Department of Education, Eastern Cape Province 200829 ILJ 2129 (HHA); en Tsika v Buffalo City Municipality 200930 ILJ 105 (OK)).

Die ontwikkeling van die gemenereg en meer spesifiek die gemeenregtelike dienskontrak ingevolge die konstitusionele voorskrifte van artikels 8(3) en 39(2) van die Grondwet van 1996 ten einde dit in ooreenstemming met die Handves van Menseregte te bring, het ' $n$ welkome dog effe omstrede verloop gehad totdat dit deur 'n vreemde "ommekeer" van sienswyse tot stilstand gebring is.

Teen hierdie agtergrond sal die omstrede saak van SA Maritime Safety Authority v McKenzie (2010 31 ILJ 529 (HHA)) bespreek word waarin gemelde tendense, beslag ontvang het asook die verskillende sienswyses wat in reaksie daarop gevolg het.

\section{Pro-ontwikkeling-regspraak}

Die verloop en ontwikkeling van die gemenereg in arbeidsregtelike verband het aanvanklik beslag gekry, interessant genoeg, in 'n drietal onlangse beslissings van die Hoogste Hof van Appèl. Die Hof het telkens in hierdie onderskeie beslissings verklaar dat die beginsel van billike arbeidspraktyke wat in artikel 23(1) van die Grondwet vasgelê word, ook die grondslag van die gemeenregtelike verpligting van goeie trou vorm wat die partye jeens mekaar in 'n dienskontraktuele situasie besit (sien Old Mutual Assurance Co SA Ltd v Gumbi 200728 ILJ 1499 (HHA); en Boxer Superstores Mtatha v Mbenya 200728 ILJ 2209 (HHA)). In eersgemelde beslissing is die volgende belangrike beginsel neergelê: "It is clear however that coordinate rights [co- 
ordinate with the contractual right] are now protected by the common law: to the extent necessary, as developed under the constitutional imperative (s 39(2)) to harmonize the common law into the Bill of Rights (which itself includes the right to fair labour practices (s 23(1))" (1501 F-G). In beide hierdie beslissings was die Hof verder van oordeel dat ' $n$ werknemer op grond van bogemelde oorwegings, soos die geval in die statutêre bedeling van WAV, op 'n kontraktuele reg op 'n voor-ontslag ("pre-dismissal") dissiplinêre verhoor geregtig is.

In Murray v Minister of Defence (2008 29 ILJ 1369 (HHA)) het die Hoogste Hof van Appèl by monde van appèlregter Cameron beslis dat die grondwetlike waarborg van billike arbeidspraktyke (art 23(1)) ook 'n nie-WAV werknemer ten dienste staan wat bedank as gevolg van die onuithoudbare ("intolerable") optrede van sy werkgewer en aan hom beskerming bied deur bemiddeling van die grondwetlik-ontwikkelde gemenereg. Hierdie arbeidsregtelike situasie word deur Cameron sinvol as volg verduidelik:

\begin{abstract}
"However, it is in my view best to understand the impact of these rights ("right to fair labour practices", etcetera) (my invoeging) on this case through the constitutional development of the common law contract of employment. This contract has always imposed mutual obligations of confidence and trust between employer and employee. Developed as it must be to promote the spirit, purport and objects of the Bill of Rights, the common law of employment must be held to impose on all employers a duty of fair dealing at all times with their employees - even these the LRA does not cover" (1374A-B).
\end{abstract}

Die Hof bevestig dus dat beide partye uit hoofde van die goeie-trouverhouding tussen hulle, ook 'n reg op billike behandeling ("fair dealing") teenoor mekaar besit en herbevestig ook dat alle kontrakte (insluitende dienskontrakte) aan noukeurige grondwetlike ondersoek ("scrutiny") onderhewig is $(1375 \mathrm{~F})$.

'n Vierde onlangse beslissing waarin hierdie positiewe tendens aandag en onderskraging gevind het, is Mogothle $v$ Premier of the Northwest Province (2009 30 ILJ $605(\mathrm{AH})$ ). Die Arbeidshof wys daarop dat die ontwikkeling van die gemenereg kontroversiële komponente besit, maar dat die Hoogste Hof van Appèl onteenseglik ' $n$ kontraktuele reg op billike behandeling ("fair dealing") gevestig het wat onafhanklik van enige statutêre reg op beskerming teen onbillike ontslag en onbillike arbeidspraktyke bestaan. In casu beslis die Hof dat by die bepaling of 'n skorsing hangende dissiplinêre optrede, die audi alteram-reël steeds relevant is by die vasstelling of billike behandeling plaasgevind het en gevolglik is 'n werknemer geregtig op 'n geleentheid om aangehoor te word alvorens enige finale besluit om hom te skors, geneem word.

Oor die ontwikkeling van die gemenereg, laat Van Niekerk $\mathrm{R}$ homself "diplomaties" as volg uit:

"As controversial as the judgments in Gumbi; Boxer Superstores and Murray might be as a matter of law or policy, they unequivocally acknowledge a common law contractual obligation on an employer to act fairly in its dealings with employees. This obligation has both a substantive and a procedural dimension. In determing the nature and extent of the mutual obligation of fair dealing as between the employer and the employee, the court must be guided by the unfair dismissal and unfair labour practice jurisprudence developed over the years. If any 'dual stream' jurisprudence emerges as a consequence and if 
this represents an undesirable outcome from a policy perspective, that is a matter for the legislature to resolve" $(615 \mathrm{E}-\mathrm{H})$.

\section{$3 \quad$ Skrywers}

Die kontroversie, hierbo na verwys, het ontstaan nadat kritiek uitgespreek is oor die wyse waarop die gemenereg arbeidsregtelik in bogemelde drietal Appèlhofsake ontwikkel is ten einde dit in ooreenstemming met algemeen aanvaarde en bekende statuutregtelike beginsels en leerstukke te bring veral ten aansien van die ontslag van werknemers. Le Roux ("Individual Labour Law" 2008 Current Labour Law 3) kritiseer die Gumbi- en Boxer Superstores-beslissings al sou dit' $n$ onnodige en kompeterende stel regsreëls naas dié vervat in WAV, skep. Artikel 8(3) van die Grondwet vereis slegs dat die gemenereg ontwikkel moet word tot die mate dat wetgewing nie erkenning aan so ' $\mathrm{n}$ reg verleen nie. Die WAV met sy betrokke beskerming teen onbillike ontslag, verleen die vereiste beskerming teen onbillike ontslag aan werknemers in beide hierdie gevalle. Le Roux wys daarop dat die Murray-saak (supra) handel oor ' $\mathrm{n}$ werknemer wat nie onder die bestek van WAV ressorteer nie en gee toe dat die Hof derhalwe geregtig was om die gemenereg in hierdie konteks te ontwikkel, onderhewig aan die bepalings van artikel 8(3)(b) van die Grondwet. Hy verklaar ook dat die Hof se aanname van 'n algemene verpligting van "fair dealing" en die meegaande ontwikkeling van toepaslike gemeenregtelike beginsels, in nog 'n stel reëls kan resulteer wat kompeteer met die definisie van 'n onbillike arbeidspraktyk soos vervat in artikel 186(2) van WAV. Le Roux is nie heeltemal oortuigend in sy sienswyse nie aangesien die verpligting van billike behandeling ("fair dealing") nie aan artikel 186(2) aan WAV ontleen is nie, maar aan artikel 23(1) van die Grondwet wat in elk geval 'n baie wyer betekenis as artikel 186(2) besit (sien ook NEHAWU v University of Cape Town 200324 IJL 95 (KH); en oor die gelding van billikheid in die algemeen by dienskontraktuele verhoudings NUMSA v Vetsak Co-operative Ltd 199617 ILJ 455 (A)).

Met verwysing na die beslissings van Gumbi en Boxer Superstores is Pretorius en Myburgh ("A Dual System of Dismissal Law" 2007 ILJ 2172) ook krities oor bogemelde ontwikkeling van die gemenereg omdat dit ' $n$ dualistiese stelsel van ontslagreg tot gevolg het. Hulle is van mening dat die jurisdiksionele onderskeid tussen die arbeidshowe en hoë howe ten opsigte van ontslaggeskille afgetakel sal word tot by 'n punt van induiestorting. Die retoriese vraag word ook gevra of daar een jurisdiksie vir dié wat dit kan bekostig (Hoë Hof) sal wees en ander vir die wat dit nie kan bekostig nie (CCMA). Die skrywers se sienswyses is egter nie heeltemal korrek nie, want die eenvoudige realiteit is dat daar alreeds 'n dualisme van stelsels (aksiegronde) bestaan ingevolge waarvan ' $n$ werknemer wie se dienste beëindig is, verhaal kan kry. Dit is ' $n$ realiteit wat alreeds die afgelope 30 jaar bestaan en daar is geen sprake van aftakeling van die tradisionele onderskeid tussen die hoër howe en die arbeidshowe nie, want in elke hof beskik 'n party oor sy eiesoortige remedies, behalwe ingevolge artikels 77(3) en 77A(e) van die Wet op Basiese Diensvoorwaardes, 75 van 1997 waar selfs 'n groter keuse 'n party ten dienste staan (sien ook Fedlife Assurance Ltd $v$ Wolfaardt 200122 ILJ 2407 (HHA); and Fredericks v MEC for Education \& Training, Eastern Cape 200223 ILJ $81(\mathrm{KH}))$. 
Cheadle ("Labour Law and the Constitution" 2008 Current Labour Law 180-182) het ook ernstige voorbehoude oor die ontwikkeling van die gemenereg op die terrein van voor-ontslag-verhore. Hy is van mening dat die gebiedende voorskrif van artikel 8(3) van die Grondwet slegs toepassing vind indien daar nie wetgewing bestaan wat effek aan so 'n reg verleen nie - en volgens hom bestaan daar reeds sodanige wetgewing. Volgens my mening is hierdie interpretasie van artikel 8(3) van die Grondwet deur Cheadle nie korrek nie aangesien daar geen wetgewing ten aansien van die gemeenregtelike dienskontrak rakende ontslag, skorsing, ensovoorts bestaan nie, behalwe artikel 23(1) van die Grondwet. Van Eck ("The Right to Pre-Dismissal Hearing In Terms of the Common Law" 2008 Obiter 339) ondersteun die besware van Pretorius, Myburgh en Cheadle (supra) en doen aan die hand dat die jurisdiksie van die Arbeidshof ten opsigte van die ontslag van werknemers beskerm moet word deur ingryping van die Konstitusionele Hof.

Du Toit verklaar dat Gumbi en Boxer Superstores "resuscitated all the problems that the LRA and BCEA sought to avoid: competing jurisdition, ... uncertainty about process ..." ("A Common-law Hydra emerges from the forum-swopping Swamp" 2010 ILJ 21 37). Die standpunt is nie heeltemal korrek nie aangesien die uitsprake van Chirwa v Transnet Ltd (2008 29 ILJ 73 $(\mathrm{KH})$; en Gcaba (supra) hopelik die onsekerhede rakende jurisdiksie en prosedures uit die weggeruim het. Hy sluit af deur aan te voer dat die "resuscitation of common-law remedies" ten koste van die statutêre bedeling ongevraagd is en dat die "subsequent 'development' of the common law in Gumbi, Boxer Superstores and Murray has compounded the confusion" 9 42). Die probleme wat $\mathrm{Du}$ Toit voorsien in verband met die duplisering van prosedures, remedies en grootskaalse verwarring, word later hieronder bespreek (sien in die algemeen ook Van Jaarsveld "Battling between Contract and Statute after Dismissal - Seeking Clarity amidst Judicial Disparity" professorale intreerede UNISA 27 November 2009; en Le Roux Current Labour Law (2012) 2-9).

\section{$4 \quad$ SA Maritime Safety Authority v McKenzie}

In die McKenzie-saak (supra) is 'n hoof-interne-ouditeur (M) deur SAMSA ontslaan waarop $M$ 'n onbillike ontslaggeskil na KVBA ingevolge die bepalings van WAV verwys het. ' $n$ Skikking word bereik tussen die partye ingevolge waarvan ' $\mathrm{n}$ jaar se salaris aan hom betaal word, maar daarna stel $\mathrm{M}$ ' $\mathrm{n}$ eis vir skadevergoeding vir R5.2 miljoen teen SAMSA in. M het aangevoer dat sy aksie daarop gebaseer is dat sy dienskontrak onderhewig was aan ' $\mathrm{n}$ uitdruklik-alternatiewelik 'n geïmpliseerde, verder alternatiewelik 'n stilswyende voorwaarde dat sy dienskontrak nie deur SAMSA sonder 'n grondige rede ("just cause") beëindig sal word nie. Hy beweer dat hierdie voorwaarde deur SAMSA verbreek is as gevolg van sy onbillike ontslag aangesien hy vir laasgenoemde tot en met sy aftrede sou gewerk het.

Die hof, by monde van waarnemende appèlregter Wallis, laat hom oor verskeie kwessies uit, maar oor die aangeleentheid onder bespreking, te wete die inkorporasie of invoering van die beginsels van billikheid of ander statutêre regte deur die howe, deur die gemeenregtelik ontwikkeling van dienskontrakte, word die volgende beslis: 
"The employment relationship is governed both by rights that are created by agreement, and by rights that are statutorily conferred, each of which has its proper place and falls to be indicated in its appropriate sphere. In by far the majority of cases the rights and obligations that are created by contract will play the lesser role and statutory rights of employees will come to the fore. In some instances the converse will be true. In either cases I can see no justification for mechanically duplicating statutory rights by importing them into the contract with the unfortunate consequences .... I can see even less justification for importing them in part only with a view to procuring advantages not contemplated by the statute.

[37] I share the view of Professor Halton Cheadle ... that where, as here, the employees are protected by the LRA, s 8(3) of the Constitution does not warrant or require an importation from the realm of constitutionally protected labour rights into individual contracts of employment by way of implied term. The LRA specifically gives effect to the constitutional right to fair labour practices and the consequent right not to be unfairly dismissed. Accordingly the constitutional basis for developing the common law of employment and thereby altering the contractual relationships is absent" (548A-F).

Soos later aangetoon sal word, is die siening eenvoudig nie suiwer nie aangesien daar geen wetgewing, met die uitsondering van artikel 23(1) van die Grondwet, bestaan wat die kontraktuele remedies van 'n werknemer reguleer as hy onregmatig ontslaan word nie. Verder kan daar ook nie besware teen "duplicating statutory rights" wees nie aangesien elke reg (remedie) op sy eie aksiegronde gebaseer is en die gemeenregtelike dienskontrak se ooreenstemmende regte nie statutêr is nie, maar deur stilswyende regwerking geld. Die hof leun ook aan op die bekende, dog omstrede Engelse beslissing van Johnson $v$ Unisys Ltd ([2001] 2 All ER 801 (HL)) vir steun van sy standpunte (laasgenoemde omstrede beslissing word hieronder bespreek).

Die Appèlhof was ook van mening dat nie enige van die onlangse sake (Gumbi, Boxer Stores en Murray) gesaghebbend beslis het dat die gemenereg ontwikkel moet word

"by importing into contracts of employment generally rights flowing from the constitutional right to fair labour practices. It is uncontroversial that the LRA is intended to give effect to that constitutional right and I see no present call, ..., for the common law to be developed so as to duplicate those rights (at least so far as it relates to employees who are subject to that Act).

[56] In my view the interpretation given to the cases mentioned goes further than the judgments warrant and they provide no obstacle to the correctness of the analysis set out above. That analysis concludes that, in so far as employees who are subject to and protected by the LRA are concerned, their contracts are not subject to an implied term that they will not be unfairly dismissed or subjected to unfair labour practices. Those are statutory rights for which statutory remedies have been provided together with statutory mechanisms for resolving disputes in regard to those rights" (553C-554A).

Die Hof bevind gevolglik dat die dienskontrak van die werknemer nie onderhewig was aan enige voorwaarde dat die werkgewer (SAMSA) nie sy kontrak sonder geregverdigde oorsaak (rede) sou beëindig nie. Indien die werknemer die hof a quo versoek het om sy gemeenregtelike dienskontrak ooreenkomstig artikel 8(3) van die Grondwet te ontwikkel en te beslis dat op grond van die grondwetlike waarborg van billike arbeidspraktyke (artikel 23(1)), werkgewers 'n verpligting het om dienskontrakte nie sonder 'n gegronde rede of oorsaak te beëindig nie, sou die geskil dalk 'n ander verloop gehad het. Die uitlatings wat die Appèlhof (my mening obiter) oor die 
ontwikkeling van die gemeenregtelike dienskontrak gemaak het, en waaroor die dicta hierbo handel, is kontroversieel en verg later (sien paragraaf 7 infra) verdere kommentaar.

\section{$5 \quad$ Regsvergelykende oorsig}

In die Engelse reg bestaan dieselfde soort dualisme tussen die gemeenregtelike dienskontrak en 'n statutêre bedeling wat onbillike ontslagte reguleer. Andersins verskil die arbeidsregtelike opset in Engeland heelwat van die Suid-Afrikaanse bedeling, soos onder andere die gelding van artikel 23(1) van die Grondwet, wat verreikende implikasies vir die Suid-Afrikaanse gemeenregtelike dienskontrak het.

In die bekende Engelse Hoë Hof ("House of Lords") -uitspraak van Johnson $v$ Unisys ([2001] ICR 480) is beslis dat die kontraktuele verpligting van "trust and confidence" nie van toepassing is op die ontslag of die wyse van ontslag van 'n werknemer nie, maar slegs op die "preserving the continuing relationship of employment". Lord Nicholls of Birkenhead verklaar onder andere dat "a common-law right embracing the manner in which an employee is dismissed cannot satisfactorily co-exist with the statutory right not to be unfairly, dismissed". Hy wys verder daarop dat die omvattende statutêre bedeling onoorkombare probleem vir die verdere ontwikkeling van die gemeenregtelike regte sal skep.

Die Unisys-saak (wat nie 'n eenparige uitspraak was nie) is egter skerp in Engeland gekritiseer deur kommentators. Die bekende Engelse akademikus Prof Hugh Collins (Employment Law 2e uitg (2010) 166) wys daarop dat die "distinction" wat uit die uitspraak voortvloei en die implikasies daarvan "has proved complex and unpredictable" en dat die "distinction also produces the odd result in the common law that ..." Hy sluit sy kritiese opmerkings oor hierdie aangeleentheid as volg af:

"The court was determined to block this route around the limits of the statutory claim, even at the expense of creating some unworkable and unpersuasive doctrinal distinctions". (Sien ook Eastwood v Magnox Electric [2005] AC 503 (HL); en in algemeen Deakin en Morris Labour Law 5e uitg (2009) 110-115).

\section{$6 \quad$ Post-McKenzie regspraak}

Die McKenzie-saak (supra) het die afgelope jaar in enkele ander hofuitsprake ook ter sprake gekom. In Mahlalela v Pension Fund Adjudicator (2011 32 ILJ $1932(\mathrm{AH})$ ) verklaar die hof bloot dat die "latest pronouncement of the SCA on the non-existence of a contractual duty of fairness must prevail".

In Lebu v Maquassi Hills Municipality (1) (2012 33 ILJ 642 (AH)) huldig Steenkamp $\mathrm{R}$ die volgende mening: "The sentiments expressed by Van Niekerk $\mathrm{J}$ in Mogothle are therefore still applicable to the case before me, even if no general right to fair dealing can be implied in the contract of employment." (Sien ook Biyase v Sisenke District Municipality 201233 ILJ $598(\mathrm{AH})$ ); die McKenzie-beslissing vind ook indirek vroeër ondersteuning in Mohlaka v Minister of Finance (2009 30 ILJ 622 (LC)) op basis daarvan dat daar alreeds wetgewing op die breër arbeidsregtelike terrein bestaan wat statuutregtelike remedies verskaf. Kritiek teen laasgemelde beslissing is dat 
daar juis geen arbeidswetgewing bestaan ten opsigte van die onderhewige gemeenregtelike arbeidsprobleme nie).

In bogemelde regspraak word die meriete van bogemelde strydvraag nie verder bespreek nie en ag die howe hulle regtens gebonde aan die McKenzie-uitspraak (supra) - egter ten onregte. In Makambi v MEC Department of Education, Eastern Cape (supra) is beslis dat indien twee hoër howe oor dieselfde beginsel konflikterende uitsprake gee, 'n laer hof geregtig is om te besluit watter een nagevolg moet word (sien ook Nakin v MEC, Department of Education, Eastern Cape Province 200829 ILJ 1426 (OK) waar by implikasie dieselfde beslis is). In casu was die Arbeidshof dus telkens nie aan die McKenzie-uitspraak gebonde nie maar het oor ' $n$ keuse beskik om óf die McKenzie-beslissing.

\section{$7 \quad$ Kommentaar en slotsienswyses}

Die McKenzie-beslissing is, soos aangetoon, in 'n swaar kleed van omstredenheid gehul. So verklaar Mischke onder andere: "Plainly, the net effect of the Supreme Court of Appeal's analysis is that everyone misunderstood or misconstrued (or misapplied) the three earlier decisions that had led to so much controversy" (Mischke 20108 Contemporary Labour Law 78). In dieselfde trant laat Grogan hom ook oor die uitspraak uit wanneer hy onomwonde verklaar: "However, in SAMSA the same court held that these judgments do not say what everybody thought they had said, and come close to saying that if they did say what everybody had thought they said, the judgments were wrong" (Collins Employment Law 21).

Die weerstandigheid van die Cheadle-Wallis benadering teen die verdere gemeenregtelike ontwikkeling van die dienskontrak ooreenkomstig die voorskrifte van die Grondwet, skep in beginsel baie probleme en derhalwe is die Cameron-Van der Walt sienswyse regtens meer aanvaarbaar en bevredigend uit 'n billikheidgesigspunt. Die vertrekpunt van die Hof in SAMSA is egter korrek dat die diensverhouding van werknemers gereguleer word deur regte wat verskillende ontstaansbronne het, naamlik volgens ooreenkoms (gemenereg) of statutêr, elkeen met 'n eie prosedure (sien ook Fedlife Assurance Ltd $v$ Wolfaardt supra; Chirwa $v$ Transnet Ltd supra). Suiwer gesien is daar egter ook 'n derde aksieproses, naamlik 'n semi-statutêre proses ingevolge waarvan kontraktuele eise, op artikel 77(3) van die Wet op Basiese Diens-voorwaardes 75 van 1997, gebaseer, in die Arbeidshof aangehoor kan word (sien Mogothle $v$ Premier of the Northwest Province supra) en waar onder andere spesifieke nakoming, skadevergoeding of kompensasie verhaal kan word (artikel 77A(e) van WBV). Die Hof gaan in McKenzie voort deur 'n belangrike kwalifikasie of voorwaarde neer te lê, naamlik dat elkeen van die stelsels of prosedures onafhanklik van mekaar funksioneer ("each of which has its proper place and falls to be vindicated in its appropriate sphere" - (supra par 36).

As bostaande waar en korrek is, (nl, dat elkeen "has its proper place") dan ontstaan die sleutelvraag waarom die drie stelsels nie ten volle onafhanklik, naas mekaar kan bestaan, ontwikkel, funksioneer en mekaar wedersyds kan verryk nie (sien ook Mogothle-saak (supra)). Indien 'n statutêre stelsel bestaan wat aan ' $n$ werknemer wat onbillik ontslaan is, $X$ aantal regte verleen, waarom kan 'n gemeenregtelike stelsel wat aan 'n ontslane werknemer slegs minder 
as $\mathrm{X}$ aantal regte verleen, nie ingevolge konstitusionele voorskrifte ontwikkel word om aan so ' $n$ werknemer ook $X$ aantal regte te verleen nie? Regtens bestaan daar geen interaksie tussen die verskillende prosesse nie - elkeen het sy eie aantal regte, remedies, vereistes en beperkings. Die individuele werknemer moet telkens in die lig van sy eie persoonlike omstandighede 'n besluit neem en 'n keuse uitoefen oor watter prosedure (aksiegrond) hy wil aanwend om verhaal te verkry. Juis in die Mogothle-saak is erkenning aan die reg op billike behandeling ("fair dealing") verleen deur die ontwikkeling van die gemeenregtelike dienskontrak. Interessant genoeg het die Hof erkenning aan addisionele skorsingsregte verleen wat nie statutêr deur WAV erken word nie.

Die drie prosedures (maar twee aksiegronde) is egter nie dupliserend van aard nie aangesien ten aansien van elkeen bepaalde sleutelvereistes alreeds vasgelê, is wat inteendeel ook verwarringstigting aan bande lê, naamlik die tydslimiete wat geld vir die instel van die gedinge, die remedies beskikbaar vir partye, eiesoortige prosedure-maatreëls wat vir elke hof geld, ensovoorts. Dit is inderdaad korrek om in hierdie konteks aan te voer dat sodanige verdere ontwikkeling van die gemeenregtelike dienskontrak beslag aan 'n kompeterende stel regsreëls naas die van WAV gee. Dit is egter onbegryplik hoekom sodanige kompetisie as ' $n$ negatiewe ontwikkeling beskou moet word aangesien dit alreeds die posisie sedert die vroeë 1980's (afgelope 30 jaar) was en sal sodanige kompetisie verder die wetgewer forseer om ook die tekortkominge van die statutêre bedeling gereeld aan te spreek sodat daar uiteindelik nie veel sprake van kompetisie hoef te wees nie. Die teendeel is egter waar, soos Grogan tereg opmerk: "The entrenchment of labour rights in general terms raises the prospect of a constitutional jurisprudence being developed by the civil courts and the Constitutional Court that may have a farreaching effect on the way the contract of employment and the employment relationship are approached in future. This could lead to a cross-fertilization of principles of labour law, the common law and public law." (Grogan Workplace Law 10e uitg (2009) 6). Hierby kan aangesluit word deur te verklaar dat die gemenereg nie uit 'n stel verstarde regsreëls bestaan wat rigied en onbuigsaam is nie. Inteendeel, dit leen dit ook tot 'n buigsaamheid, moderne dinamika en sinvolheid wat ten duidelikste uit die trilogie van Gumbi-, Boxeren Murray-uitsprake geblyk het. (Sien ook Martin v Murray 199516 ILJ 589 (K) 601 waar verklaar is dat die gemenereg nie beskou moet word as "an ossified code of immutable principles which can only be changed by legislation"). As die drie stelsels of prosedures onafhanklik van mekaar bestaan en funksioneer, dan volg dit dat die Cheadle-Wallis standpunt dat die grondwetlike voorskrif van artikel 8(3) nie toepassing kan vind omdat daar wetgewing bestaan wat aan 'n bepaalde statutêre reg beslag gee, nie korrek of aanvaarbaar is nie. In nie een van die vroeëre Hoogste Hof van Appèlsake of die Mogothle-saak, was daar alreeds wetgewing op die betrokke dienskontrakte van toepassing wat voorsiening gemaak het vir die statutêre ontslag- of ander relevante dissiplinêre regte nie, behalwe artikel 23(1) van die Grondwet nie.

'n Geval wat die Cheadle-Wallis denkskool hoofbrekens besorg, is die feitesituasie wat hom in die Murray-saak (supra) voorgedoen het, waar die betrokke werknemer van die toepassing van die Wet op Arbeidsverhoudinge van 1996 uitgesluit is. In hierdie geval is daar blykbaar nie veel besware om sogenaamde "pakket statutêre regte" aan so 'n werknemer te laat toekom 
deur die gemeenregtelike ontwikkeling van sy dienskontrak ooreenkomstig die grondwetlike voorskrif van artikel 8(3) nie. As dit so is, ontstaan die vraag dadelik waarom werknemers wat wel onder die WAV-bedeling ressorteer, maar as gevolg van persoonlike omstandighede en redes verkies om die gemeenregtelike roete te volg (wat hulle ten volle geregtig is om te doen), teen gediskrimineer word deur hulle te ontneem van die waarborg van billike arbeidspraktyke en a consequenter van die beskerming van ' $\mathrm{n}$ voorverhoorontslag, ' $n$ ontslag met gegronde redes, substantiewe en prosessuele billike skorsing, ensovoorts. Weereens, as dit in gedagte gehou word dat elkeen van die drie stelsels onafhanklik naas mekaar bestaan en funksioneer, met sy eiesoortige voor- en nadele vir elke werknemer-litigant, is dit nie so uitdagend om die betrokke denkskuif te maak nie.

Ten slotte moet die opmerking miskien ook gemaak word dat die Hoogste Hof van Appèl in die McKenzie-uitspraak twee regsaspekte met mekaar verwar het, te wete "die invoering van geïmpliseerde voorwaardes" aan die een kant en "die konstitusionele ontwikkeling van die gemeenregtelike dienskontrak" aan die ander kant. Dit is korrek om te verklaar dat die gemeenregtelike dienskontrak nie ontwikkel kan word deur statutêre regte van WAV daarin te impliseer nie - maar om die volgende redes is dit nie korrek om te verklaar dat laasgemelde kontrak nie ingevolge grondwetlike voorskrifte ontwikkel kan word deur die invoering van bepaalde statutêre regte nie: eerstens, aangesien artikel 8(3) van die Grondwet nie voorsiening vir so 'n verbod maak nie en tweedens, dit nouliks betoog kan word dat die beskerming van artikel 23(1) van die Grondwet nie geld vir gemeenregtelike dienskontrakte nie (sien ook NEHAWU v University of Cape Town supra). Verder, as dit so is dat artikel 23(1) van die Grondwet ook op alle gemeenregtelike dienskontrakte van toepassing is en werknemers derhalwe op billike arbeidspraktyke geregtig is, waarom is dit onaanvaarbaar om dieselfde beginsel te herformuleer, in ander woorde, deur te verklaar dat werknemers op billike behandeling ("fair treatment") geregtig is? Aangesien die primêre geskilpunt in McKenzie oor die bestaan of nie van 'n geïmpliseerde term in 'n dienskontrak en nie oor die gemeenregtelike ontwikkeling daarvan, gehandel het nie, is die sienswyses van die hof oor laasgemelde aangeleentheid obiter en is dit dus nie bindend, nie maar besit dit moontlike oorredingskrag.

Hierdie onwilligheid om die gemeenregtelike dienskontrak onafhanklik van die statutêre WAV-bedeling sinvol grondwetlik te ontwikkel, regverdig volgens my mening die kritiek wat op die Wallis-Cheadle-benadering deur Mischke (supra) uitgespreek is, toe hy verklaar het: "As it stands, this latest decision of the Supreme Court of Appeal does not clear up the confusion; it may, on the contrary, muddy the waters in respect of some aspects even more" (supra 79). Miskien is dit egter gepas om op 'n positiewe noot af te sluit met die volgende gevierde woorde van wat reeds in 2005 uitgespreek is:

"Perhaps the time has come for us to stop suppressing the common law in the area of labour law and to accept that it is a part of life that needs more regulation but like death and taxes is always with us" (Wallis "The LRA and the Common Law" 2005 9(2) LDD 137).

Fanie van Jaarsveld Universiteit van Pretoria 